\title{
Indium In-111 Pentetreotide
}

National Cancer Institute

\section{Source}

National Cancer Institute. Indium In-111 Pentetreotide. NCI Thesaurus. Code C1672.

An indium 111 radioconjug ate of pentetreotide, the diethylenetriaminopentaacetic (DTPA) conjug ate of the human hormone somatostatin peptide analogue (octreotide), used for radioimaging neuroendocrine tumor cells. The pentetreotide moiety of indium In 111 pentetreotide binds to somatostatin receptors (SST Rs), especially type 2 receptors, present on the cell membranes of many types of neuroendocrine tumor cells. Upon binding and internalization, this radioconjug ate allows for specific imag ing of neuroendocrine tumors that overexpress somatostatin using scintigraphic imaging techniques. In addition, high dose indium In 111 pentetreotide may specifically deliver a cytotoxic dose of gamma radiation to SSTR-positive cells thereby killing SSTR-expressing tumor cells. 